\title{
PENDUGAAN SEBARAN AIR PAYAU DENGAN TOMOGRAFI GEOLISTRIK DI PULAU KARIMUNJAWA JAWA TENGAH
}

\author{
ESTIMATION OF BRACKISH WATER USING GEOELECTRIC TOMOGRAPHY \\ IN KARIMUNJAWA ISLAND, CENTRAL JAVA
}

\author{
Dino Gunawan Pryambodo dan Joko Prihantono \\ Pusat Riset Kelautan \\ BRSDM KP, KKP. Jl. Pasir putih 1, Ancol Timur Jakarta 14430 \\ Telp: (021) 64713850 \\ e-mail : dinogunawan77@gmail.com
}

Diterima tanggal: 14 Februari 2017 ; diterima seletah perbaikan: 31 Maret 2017 ; Disetujui tanggal: 20 April 2017

\begin{abstract}
ABSTRAK
Daerah pesisir dan pulau-pulau kecil di Indonesia umumnya mempunyai sumberdaya air yang payau karena telah terintrusi oleh air laut. Tujuan penelitian ini adalah untuk memetakan keberadaan air payau di Pulau Karimunjawa. Penelitian ini dilakukan dengan menggunakan metode tomografi geolistrik dengan konfigurasi elektroda wenner. Pengukuran dilakukan sebanyak 4 lintasan dengan panjang setiap lintasan 190 meter dan diolah menggunakan program Res2Dinv. Hasil dari tomografi geolistrik di pesisir Kecamatan Karimunjawa Pulau Karimunjawa di beberapa tempat keberadaan air payau sudah mencapai kedalaman 30 meter dari atas permukaan tanah dengan litologi batuan penyusunnya berupa batu pasir. Penyebaran intrusi air laut ini disebabkan banjir ROB yang terjadi di Pulau Karimunjawa, yang menyebabkan penurunan kualitas air bersih di tempat tersebut.
\end{abstract}

Kata kunci : Air payau, tomografi geolistrik, Karimunjawa, Res2Dinv.

\section{ABSTRACT}

The coastal areas and small islands in Indonesia generally have brackish water resources because they have been intruded by sea water. The purpose of this research was to map the presence of brackish water in Karimunjawa Island. This research was conducted by using geoelectric tomography method with wenner electrode configuration. Measurements were made of 4 lines with a length of 190 meters each and were processed using the Res2Dinv program. The result of geoelectric tomography on the coast of Karimunjawa sub-district Karimunjawa Island in some places of brackish water has reached a depth of 30 meters from the subsurface with the lithology of rocks is sandstone. The spread of sea water intrusion is due to the ROB flood that occurred in Karimunjawa Island, which caused a decrease in the quality of clean water in the place.

Keywords: Brackish water, geoelectrical tomography, Karimunjawa, Res2Dinv.

\section{PENDAHULUAN}

Pulau Karimunjawa dengan luas area sebesar $46,24 \mathrm{~km}^{2}$ (BPS Jepara, 2016) adalah pulau utama dan terbesar digugusan Kepulauan Karimunjawa. Pulau Karimunjawa ini terletak sekitar $90 \mathrm{~km}$ di sebelah utara dari dari kota Jepara, Provinsi Jawa Tengah. Secara administrasi Kepulauan Karimunjawa ini merupakan satu kecamatan yang menjadi bagian dari Kabupaten Jepara Provinsi Jawa Tengah. Kota Karimunjawa adalah Ibu kota kecamatan Karimunjawa yang terdapat di bagian selatan dari Pulau Karimunjawa .

Pulau Karimunjawa termasuk pulau kecil sesuai dengan UU No.1 tahun 2014 tentang pengelolaan wilayah pesisir dan pulau-pulau kecil yaitu pulau yang memiliki luas kurang dari $2000 \mathrm{~km}^{2}$. Berdasarkan kunjungan wisatawan sebanyak 92.115 jiwa pada tahun 2015 (BPS Jepara, 2016) Pulau Karimunjawa dijadikan tujuan wisata unggulan untuk provinsi jawa tenggah dengan diterbitkannya Perda No.10 tahun 2012, dengan adanya jumlah kunjungan wisatawan yang cukup banyak akan berpengaruh terhadap pengunaan air bersih di pulau Karimunjawa hal ini dapat dilihat dibeberapa tempat air bersihnya sudah menjadi payau (Cabral et al., 2005).

Aktivitasi pariwisata bahari di Pulau Karimunjawa telah merubah fungsi dari area konservasi menjadi area komersil yang dikhawatirkan akan menggangu keseimbangan ekosistem dan sumber daya air tawar yang menjadi air ir payau (Maulana, 2016), air payau 
ini terjadi karena intrusi air asin ke air tawar, Jika kadar garam yang dikandung dalam satu liter air adalah antara 0,5 sampai 30 gram, maka air ini disebut air payau (Febriwahyudi, 2012). Secara umum kondisi air bersih yang diperoleh dari air tanah yang mulanya memiliki kualitas bagus mengalami penurunan kualitas menjadi air payau akibat intrusi air laut. Studi tentang intrusi air laut sangat perlu untuk dilakukan (Barlow \& Richard, 2010; Werner et al., 2013) untuk mencegah kerugian yang besar bagi masyarakat terutama dalam hal kesehatan karena penggunaan air payau untuk dikonsumsi manusia dapat menimbulkan penyakit perut seperti diare (Nurtiyani, 2005). Selain adanya penurunan kualitas air layak minum, air tanah yang menjadi air payau dapat menyebabkan korosi pada pondasi bangunan apabila dalam proses pembangunan menggunakan air tanah yang sudah menjadi payau (Miswar, 2011).

Menurut Hehanussa (1993), Pulau Karimunjawa (Gambar 1) termasuk jenis Pulau petabah, Pulau petabah adalah pulau yang terbentuk di daerah yang stabil secara tektonik (Effendi, 2010). Pulau seperti ini antara lain dijumpai di Paparan Sunda. Tujuan dari penelitian ini untuk mengetahui penyebaran intrusi air payau di Pulau Karimunjawa dengan teknik geolistrik tomografi.

\section{BAHAN DAN METODE}

Survei geofisika geolistrik secara umum dibagi menjadi dua metode yaitu metode 1D atau disebut vertical electrical sounding (VES) dan 2D yang biasa disebut Electrical Resistivity Tomography (ERT), metoda ERT ini umumnya dikenal dengan tomografi geolistrik (Heen, 2017). Pada penelitian ini digunakan metoda ERT untuk menduga sebaran air payau di Pulau Karimunjawa Provinsi Jawa Tenggah.

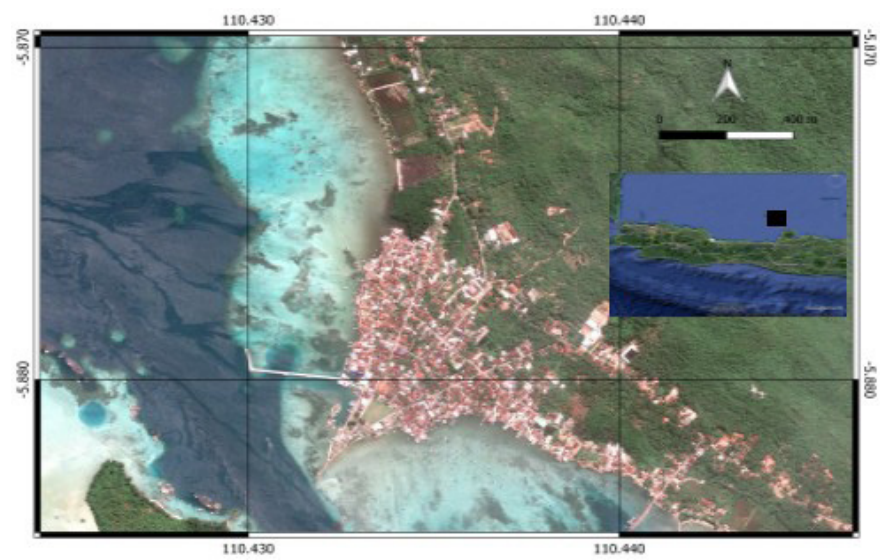

Gambar 1. Lokasi Kegiatan.

Figure 1. Activity Location.
Metode tomografi geolistrikini merupakan metode yang banyak sekali digunakan dan hasilnya cukup baik dan efektif yaitu untuk memperoleh gambaran lapisan tanah di bawah permukaan berdasarkan perbedaan nilai tahanan-jenis batuan (Zarroca et al., 2011; Abdul et al., 2013). Dalam penelitian ini, kami menggunakan instrumen geolistrik multi-elektroda dan multi-kabel untuk mendapatkan gambaran model 2D bawah permukaan berdasarkan nilai tahanan-jenis (Boko, 2016). Pendugaan tomografi geolistrik ini didasarkan pada kenyataan bahwa material yang berbeda akan mempunyai tahanan jenis yang berbeda apabila dialiri arus listrik (Wijaya, 2015). Peningkatan konsentrasi ion pada fluida akan meningkatkan konduktifitas fluida dan menurunkan nilai resistivitas batuan secara keseluruhan (Hasanudin, 2009). Satuan tahanan jenis yang digunakan adalah $\mathrm{Ohm}$ meter. Beberapa penelitian terdahulu membuktikan bahwa pengaruh kandungan air akan menurunkan nilai tahanan jenis suatu batuan, besar kecilnya penurunan nilai tahanan jenis tergantung pada kandungan air yang ada di dalam pori-pori batuan (porositas batuan) (Santoso, 2002).

Peralatan yang digunakan dalam penelitian ini adalah resistivitymeter merk Multichannel $S$ Field untuk mengukur nilai beda potensial sesuai dengan konfigurasi elektrode yang digunakan dan perlengkapan lainnya berupa 20 elektroda beserta kabelnya, GPS (Global Positioning System) Garmin tipe 78s untuk menentukan posisi lintasan, accumulator, dan perlengkapan pendukung seperti meteran, kalkulator, multi tester, dan handy talky (HT).

Dalam survei lapangan digunakan konfigurasi wenner karena resolusi yang cukup baik secara horisontal maupun vertikal dan kedalaman penetrasi yang cukup dalam (Utiya et al., 2015). Prinsip dalam metode ini yaitu arus listrik diinjeksikan ke alam bumi melalui dua elektroda arus (elektroda AB), sedangkan beda potensial yang terjadi diukur melalui dua elektroda potensial (elektroda MN). Dari hasil pengukuran arus dan beda potensial listrik, dapat diperoleh variasi harga tahanan jenis semu ( $\rho$ a) pada lapisan di bawah titik ukur (Loke \& Barkers, 1996). Keunggulan dari konfigurasi Wenner (Gambar 2) ini adalah ketelitian pembacaan tegangan (volt) pada elektroda MN lebih baik dengan angka yang relatif besar karena elektroda MN yang relatif dekat dengan elektroda AB. Disini bisa digunakan alat ukur multimeter dengan impedansi yang relatif lebih kecil. Sehingga nilai resisitivitas semu didapat dengan persamaan di bawah ini (Telford, 1990): 


$$
\begin{aligned}
\rho_{a}= & K \frac{\Delta V}{I} \\
& \text { Dimana : } \\
\rho \mathrm{a} \quad & \text { Tahanan jenis semu (ohm-m) } \\
\mathrm{K} \quad & \text { Faktor Geometri } \\
\Delta \mathrm{V} \quad= & \text { Beda potensial (mV) } \\
\mathrm{I} \quad= & \text { Kuat arus yang dialirkan (milliAmpere) } \\
\mathrm{a} \quad= & \text { Jarak antara kedua elektrode arus (AB) dan } \\
& \text { elektroda potensial (MN) }
\end{aligned}
$$

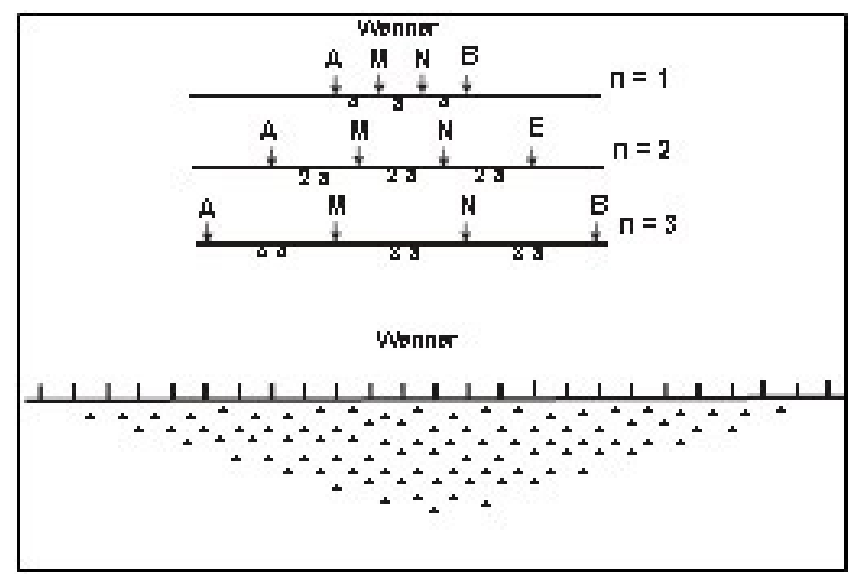

Gambar 2. Langkah pengambilan data geolistrik 2D konfigurasi Wenner (Loke, 2004) analisis data dilakukan dengan program.

Figure 2. Wenner 2D configuration data of aquisition (Loke, 2004)data analysis is done by program.

Analisis data dilakukan dengan program Res2Dinv (Loke, 2004) untuk memperoleh gambar penampang 2D yang berupa kedalaman dan nilai resistivitas pada tiap lapisan. Pada penelitian ini dilakukan beberapa langkah kerja (diagram alir) yang meliputi, permasalahan air payau yang terjadi di Pulau Karimunjawa, studi pustaka untuk mengetahui kondisi geologi daerah penelitian dan metoda yang digunakan, menentukan lintasan geolistrik tomografi dari informasi dari masyarakat tentang keberadaan air payau yang terjadi di sumur penduduk, lalu dilakukan akuisisi atau pengambilan data tomografi geolistrik dengan alat resistivitymeter merk Multichannel S Fiel, Setelah data diperoleh maka diproses dengan menggunakan software Res2Dinv. Hasil dari proses data tersebut diinterpretasikan dengan memasukan kondisi geologi di daerah penelitian, setelah itu dilakukan pembahasan dan menarik kesimpulan dari penelitian ini. Adapun diagram alir penelitian untuk pendugaan air payau dengan geolistrik 2D seperti Gambar 3.

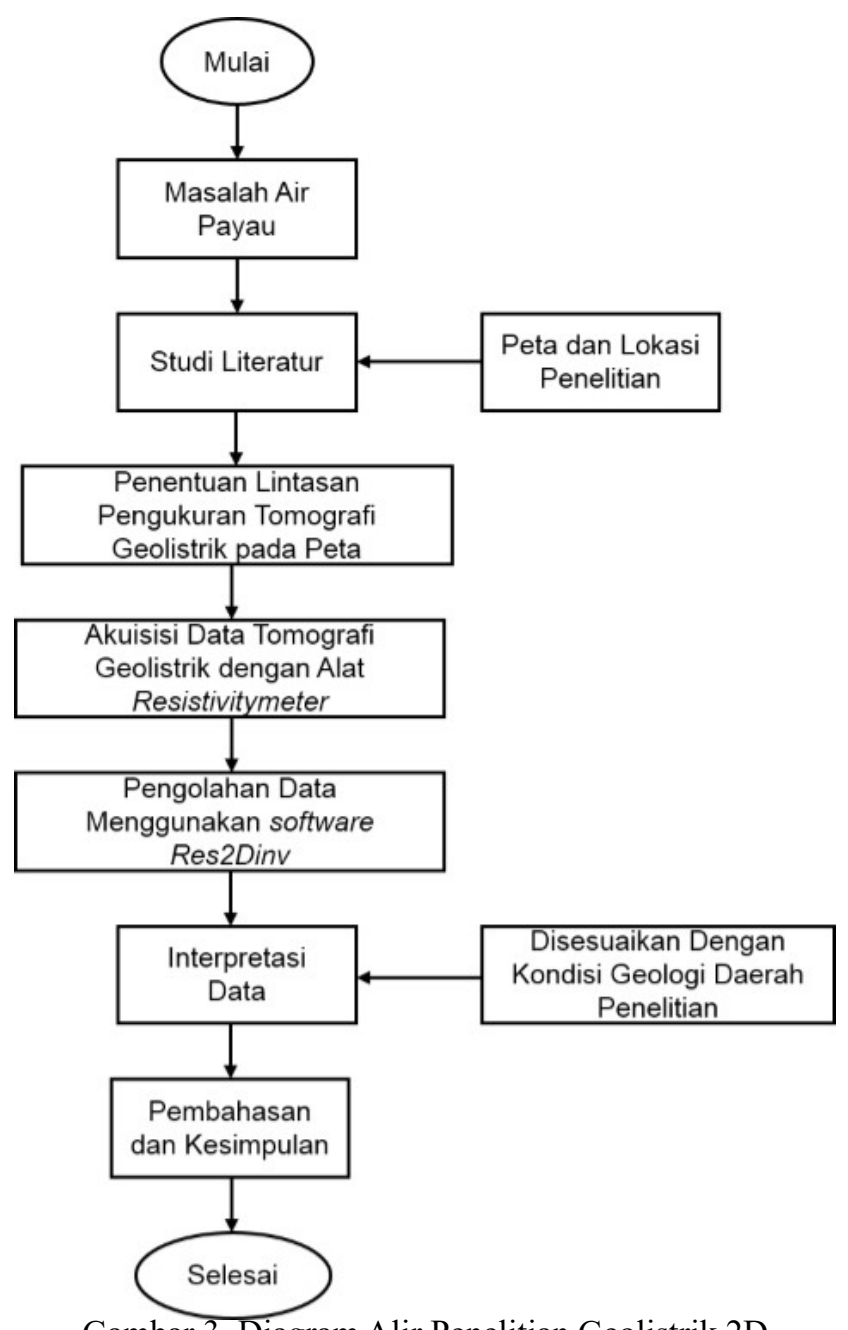

Gambar 3. Diagram Alir Penelitian Geolistrik 2D. Figure 3. 2D Geolistrik Research Flow Diagram.

\section{HASIL DAN PEMBAHASAN}

Pulau Karimunjawa adalah merupakan merupakan pulau berbukit dengan sejumlah puncak-puncak bukit kecil yang memiliki kelerengan yang relatif terjal. (Hadi, 2006) .

Secara geologi (Sidarto, 1993) Pulau Karimunjawa terdiri dari formasi Karimunjawa yang terdiri dari batuan serpih, batuan granit, batu pasir dan konglomerat. Sedangkan didaerah penelitian terdiri dari endapan pantai yang berupa alluvium (Hadi, 2006)

Hasil pengukuran dan pengolahan tomografi geolistrik dengan metode Wenner 2D di lapangan dengan software Res2Dinv dengan 5 kali iterasi dengan RMS Errornya sekitar 35,6 \% maka diperoleh 4 lintasan penampang tahanan jenis bawah permukaan di Pulau Karimunjawa (Gambar 4) dengan panjang lintasan sejauh 190 meter dengan ke dalam penetrasi yang diperoleh sedalam 34,6 meter dari atas permukaan 
tanah. Keempat lintasan tersebut yaitu lintasan 1 yang berarah baratdaya-timurlaut, lintasan 2 dengan arah lintasan baratdaya-timurlaut, lintasan 3 yang berarah baratlaut-tenggara, lintasan 4 yang berarah baratdaya-timurlaut. Berdasarkan penampang tahanan jenis bawah permukaan hasil proses pengolahan data tomografi geolistrik bisa diduga keberadaan air payau dan litologi bawah permukaannya, lihat Tabel 1 .

Tabel 1. Nilai tahanan jenis batuan di Lokasi Penelitian (Telford, 1990)

Table 1. Resistance value of rock type at research Sites (Telford, 1990)

\begin{tabular}{lll}
\hline No & Tahanan Jenis $(\boldsymbol{\Omega m})$ & Litologi \\
\hline 1 & $3,41-32,7$ & Batu Pasir \\
2 & $52,6-245$ & Batu Gamping \\
3 & $326-23.550$ & Batu Granit \\
\hline
\end{tabular}

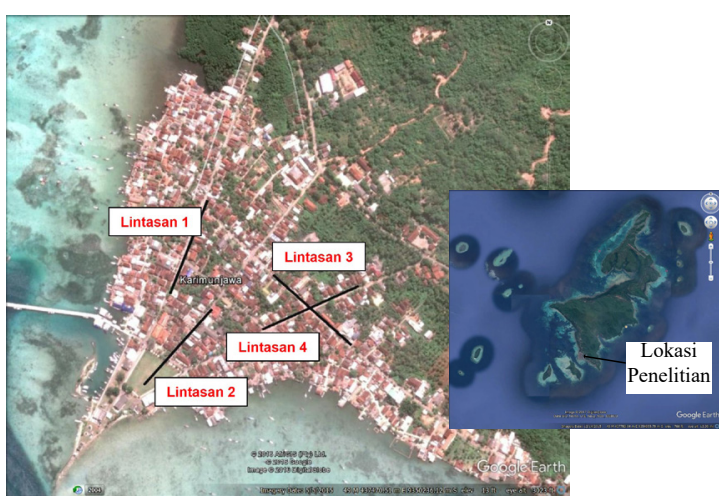

Gambar 4. Peta Lintasan Geolistrik Karimunjawa. Figure 4. Map of Karimunjawa geoelectrict Trajectory.

\section{Lintasan 1}

Lintasan 1 berada di sebelah barat kota Kec. Karimunjawa dengan arah lintasan baratdaya - timurlaut dengan panjang lintasan 190 meter dan dengan kedalaman 34,6 meter dari atas permukaan tanah. Hasil geolistrik lintasan 1 (Gambar 5) terlihat tahanan jenis yang terukur bervariasi dari nilai kurang dari 3,41 $\Omega \mathrm{m}$ sampai $2019 \Omega \mathrm{m}$ lebih, dari hasil geolistrik ini diduga telah terjadi intrusi air laut sehingga air tawar berubah menjadi air payau dengan nilai tahan jenis berkisar antara 3,41 $\Omega \mathrm{m}-21,1 \Omega \mathrm{m}$ dengan kedalam air payau kurang dari 20 meter dari atas permukaan tanah. Penyusun batuan (litologi) lintasan 1 ini berupa batu pasir, batu gamping, dan batu granit (Gambar 6) Keberadaan air payau pada lintasan 1 ini terdapat pada litologi batuan pasir.

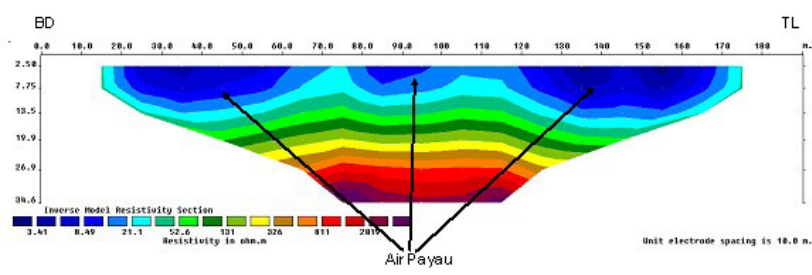

Gambar 5. Penampang geolistrik lintasan 1.

Figure 5. Trajectory of geoelectric at section 1.

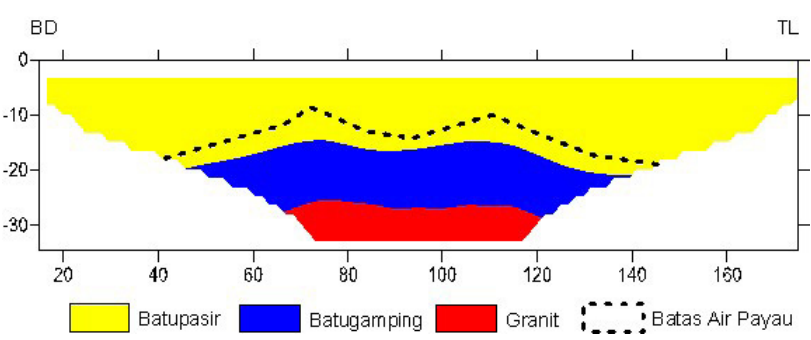

Gambar 6. Penampang litologi lintasan 1.

Figure 6. Trajectory of lithology at section 1.

Lintasan 2

Lintasan 2 ini berada di dekat kantor Kec. Karimunjawa dengan arah arah lintasan baratdaya - timurlaut melewati lapangan sepak bola kota Kec. Karimunjawa dengan panjang lintasan 190 meter dan dengan kedalaman 34,6 meter dari atas permukaan tanah. Hasil dari pengukuran geolistrik lintasan 2 (Gambar 7) dapat dilihat nilai tahanan jenis kurang dari $14,3 \Omega \mathrm{m}$ sampai $4628 \Omega \mathrm{m}$ lebih, dari hasil geolistrik ini diduga telah terjadi intrusi air laut sehingga air tawar berubah menjadi air payau dengan nilai tahan jenis berkisar antara 14,3 $\Omega \mathrm{m}-32,7$ $\Omega \mathrm{m}$ dengan kedalam air payau kurang dari 30 meter dari atas permukaan tanah. Penyusun batuan (litologi) lintasan 2 ini berupa batu pasir, batu gamping, dan batu granit (Gambar 8). Keberadaan air payau pada lintasan 2 ini terdapat pada litologi batuan pasir.

Lintasan 3

Lintasan 3 berada di tengah pemukiman penduduk dengan arah lintasan baratlaut - tenggara dengan panjang lintasan 190 meter dan dengan kedalaman 34,6 meter dari atas permukaan tanah. Hasil geolistrik lintasan 3 (Gambar 9) terlihat tahanan jenis yang terukur bervariasi dari nilai kurang dari $7,98 \Omega \mathrm{m}$ sampai 23550 $\Omega \mathrm{m}$ lebih, dari hasil geolistrik ini diduga telah terjadi intrusi air laut sehingga air tawar berubah menjadi air payau dengan nilai tahan jenis berkisar antara $7,98 \Omega \mathrm{m}$ - 25,0 $\Omega \mathrm{m}$ dengan kedalaman air payau kurang dari 23 meter dari atas permukaan tanah. Penyusun batuan (litologi) lintasan 3 ini berupa batu pasir, batu gamping, dan batu granit (Gambar 10). Keberadaan air payau pada lintasan 3 ini terdapat pada litologi batuan pasir. 


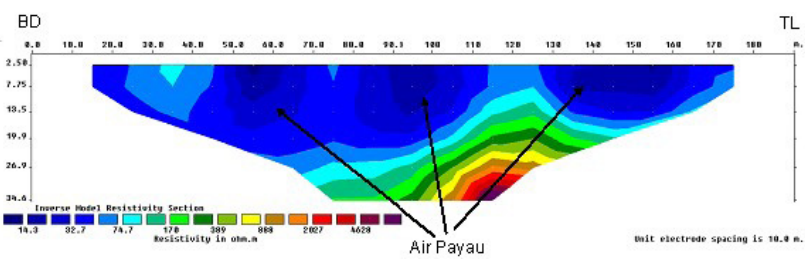

Gambar 7. Penampang geolistrik lintasan 2

Figure 7. Trajectory of geoelectric at section 2

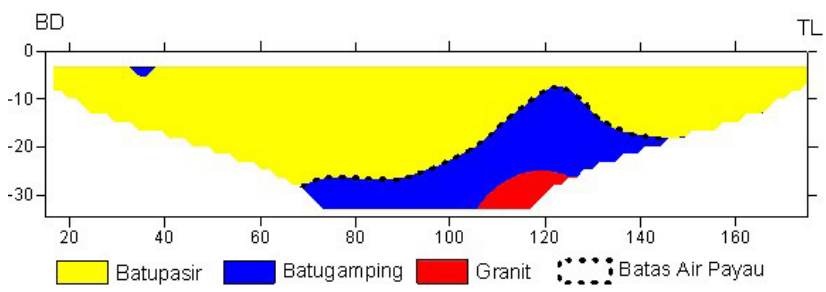

Gambar 8. Penampang litologi lintasan 2.

Figure 8. Trajectory of lithology at section 2.

Lintasan 4

Lintasan 4 berada di sebelah di tengah pemukiman penduduk dan lintasan 4 ini bersilangan (cross line) dengan lintasan 3 , dengan arah lintasan baratdaya - timurlaut dengan panjang lintasan 190 meter dan dengan kedalaman 34,6 meter dari atas permukaan tanah. Hasil geolistrik lintasan 4 (Gambar 11) terlihat tahanan jenis yang terukur bervariasi dari nilai kurang dari 4,95 $\Omega \mathrm{m}$ sampai $3350 \Omega \mathrm{m}$ lebih, dari hasil geolistrik ini diduga telah terjadi intrusi air laut sehingga air tawar berubah menjadi air payau dengan nilai tahan jenis berkisar antara 4,95 $\Omega \mathrm{m}-31,9 \Omega \mathrm{m}$

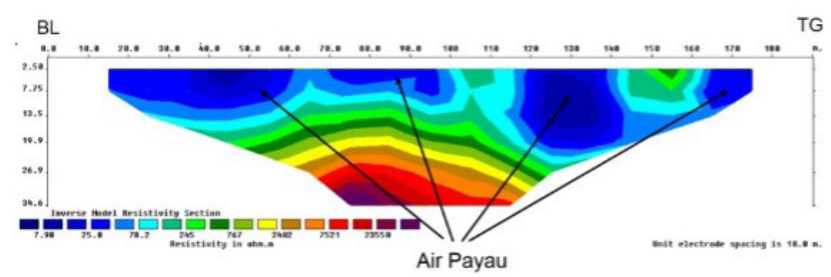

Gambar 9. Penampang geolistrik lintasan 3.

Figure 10. Trajectory of geoelectric at section 3.

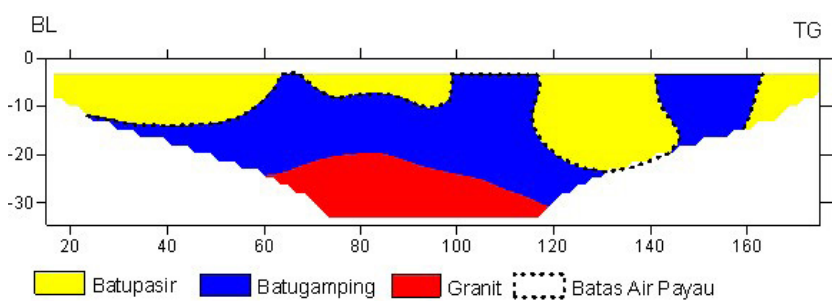

Gambar 10. Penampang litologi lintasan 3.

Figure 10. Trajectory of lithology at section 3.

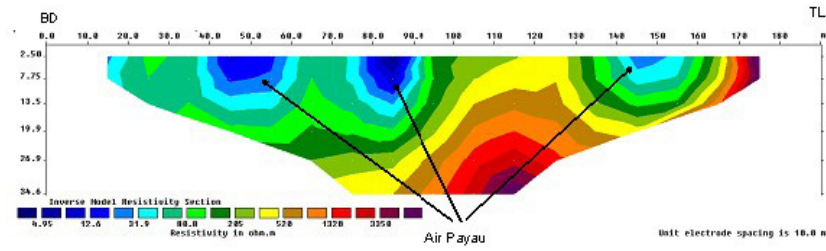

Gambar 11. Penampang geolistrik lintasan 4

Figure 11. Trajectory of Geoelectric at section 4

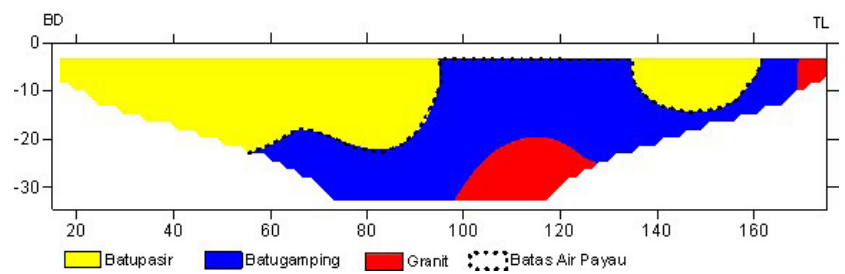

Gambar 12. Penampang litologi lintasan 4.

Figure 12. Trajectory of lithology at section 4.

dengan kedalam air payau kurang dari 20 meter dari atas permukaan tanah. Penyusun batuan (litologi) lintasan 4 ini berupa batu pasir, batu gamping, dan batu granit (Gambar 12). Keberadaan air payau pada lintasan 4 ini terdapat pada litologi batuan pasir.

Dari keempat lintasan tomografi geolistrik di pulau Karimunjawa secara keseluruhan keberadaan air payau terdapat pada litologi batu pasir yang mempunyai permeabilitas yang tinggi untuk meloloskan fluida. Berdasarkan hasil pencitraan bawah permukaan tanah dengan geolistrik tomografi pola penyebaran air payau berada di akuifer dangkal dan berbentuk lensa, sehingga penyebab terjadinya air payau di pulau Karimunjawa tepatnya di kota kecamatan Karimunjawa ini diduga akibat adanya banjir Rob yang terjadi karena pasang surut air laut yang terjadi di daerah penelitian sehingga air laut menyusup kedalam akuifer dangkal sehingga terjadinya degradasi kualitas dari akuifer ini menjadi payau.

\section{KESIMPULAN DAN SARAN}

Berdasarkan hasil penelitian ini dapat disimpulkan antara lain, hasil interpretasi dari empat lintasan tomografi geolistrik di Pulau Karimunjawa dapat menduga sebaran air payau di kota Kec. Karimunjawa. Keberadaan air payau di daerah penelitian ini terdapat pada kedalaman 2,5 meter sampai 30 meter di bawah permukaan tanah. Penyusun litologi batuan untuk keberadaan air payau disusun oleh batu pasir yang memiliki permeabilitas yang tinggi sehingga dapat meloloskan fluida. Penyebab air payau yang terjadi di Pulau Karimunjawa ini diduga karena intrusi air 
laut yang masuk kedaratan sehingga mempengaruhi kualitas air tawar pada sumur penduduk

\section{DAFTAR PUSTAKA}

BPS Jepara. (2016). Statistik Daerah Kecamatan Karimunjawa 2016, Badan Pusat Statistik Kab. Jepara.

UU No.1 tahun 2014. (2014). Perubahan atas UU No.27 tahun 2007, Tentang Pengelolaan Wilayah Pesisir dan Pulau Pulau Kecil.

Perda No. 10 Tahun 2012. (2012). Rencana Induk Pembangunan Kepariwisataan Provinsi Jawa Tenggah Tahun 2012-2027.

Cabral., Mario, M., Sutikno., Simoen., \& Soenarso. (2005). Studi Agihan Kualitas Air Tanah Bebas Berdasarkan Tipe Penggunaan Lahan Persawahan dan Pertambakan Di Pulau Karimunjawa, Jurnal Manusia dan Lingkungan Vol 12, No 2 ,UGM, Yogyakarta.

Maulana, R., \& Hadian, M. S. D. (2016). Studi Keseimbangan Air dan Konservasi Airtanah sebagai Strategi Pengelolaan Lingkungan dalam Pengembangan Pariwisata, Publikasi Ilmiah Pendidikan dan Pelatihan Geologi, Vol12 No.2, ESDM, Bandung.

Nurdiyanto, B., Suyanto, I., Sunardi, B., \& Susilanto, P. (2016). Tomografi Geolistrik untuk Identifikasi Litologi Pada Lokasi Rencana Bendung dan Terowongan di Sulawesi Utara, JURNAL METEOROLOGI DAN GEOFISIKA, VOL. 17 NO. 1, 15-23.

Febriwahyudi, C.T. (2012). Resirkulasi Air Tambak Bandeng Dengan Slow Sand Filter. Jurnal Teknik POMITS Vol.1, No. 1, Surabaya.

Barlow, P.M., \& E.G. Reichard. 2010. Saltwater intrusion in coastal regions of North America. Hydrogeology Journal 18: 247-60.

Werner A. D., Bakker M., Post V. E. A., et al. Seawater intrusion processes, investigation and management: recent advances and future challenges. Advances in Water Resources. 2013;51:3-26

Nurtiyani, E. (2005). Intrusi Air Laut: Masalah yang Semakin Mengancam. Ministry of Education and Research. ENVIHSA Fakultas Kesehatan Masyarakat. Universitas Indonesia

Miswar, Khairul. (2011). Kuat Tekan Beton terhadap Lingkungan Agresif. Jurnal Portal, Vol 3 No 2, Teknik Sipil Politeknik Negeri Lhokseumawe.

Hehanussa, P.E. (1993). Morphogenetic Classification of Small Island as basis for Resources Planningin Indonesia, Seminar on Small Island Hydrology, UNESCO-ROSTSEA, Batam Island.

Effendi, I. (2010), Karakteristik Mata Air pada Lingkungan Pembentukan Batuan Metamorf di Pegunungan Lingga, Pulau Lingga, Kepulauan Riau, Buletin Geologi Tata Lingkungan Vol.20 No. 1, Bandung.

Heen. Z.H.A. (2017), Use of Electrical Resistivity Methods (2-D and VES) in Proposed Landfill Site Investigation
- A Case Study of Al Fukhari Landfill, Southeastern Gaza Strip, Palestine, Journal of Environment and Earth Science Vol.7, No.3.

Zarroca, M., Bach, J., Linares, R., \& Pellicer, X.M. (2011). Electrical methods (VES and ERT) for identifying, mapping and monitoring different saline domains in a coastal plain region (Alt Empordà, Northern Spain). Journal of Hydrology 409, 407-422.

Abdul-Nafiu, A. K, Nawawi, M. M. N., Khiruddin, A, Ishola, K. S., \& Abdulrahman, A. (2013), Effects of Electrode Spacing and Inversion Techniques on the Efficiency of 2D Resistivity Imaging to Delineate Subsurface Features, American Journal of Applied Sciences, 10 (1).

Wijaya, A. S. (2015). Aplikasi Metode Geolistrik Resistivitas Konfigurasi Wenner untuk Menentukan Struktur Tanah di Halaman Belakang SCC ITS Surabaya, Jurnal Fisika Indonesia, No. 5 Vol X, ITS, Surabaya.

Hasanudin, M., \& Pryambodo, D. G. (2009). Studi Intrusi Air Laut di Cirebon dengan Menggunakan Metode Geolistrik, Jurnal Segara, Vol. 5.

Santoso, D. (2002). Pengantar Teknik Geofisika, Departemen Teknik Geofisika ITB, Bandung.

Geocis. (2017). S Field Resistivity Automatic Multichannel $(16 \mathrm{CH})$ (Internet), http://www.geocis.net/filedownload/S-FIELD-.pdf (diakses 6 Maret 2017).

Garmin. (2017). GPSMAP 78 series manual, http://gpscentrs. lv/instrukcijas/GPSMAP_78_OM_EN.pdf (diakses 6 Maret 2017).

Utiya, J., Asâ, A., Tongkukut., \& Seni. H. J. (2015). Metode Geolistrik Resistivitas Konfigurasi WennerSchlumberger dan Konfigurasi Dipole-Dipole untuk Identifikasi Patahan Manado di Kecamatan Paaldua Kota Manado. JURNAL ILMIAH SAINS Vol. 15 No. 2, Manado.

Loke, M.H., \& Barkers, R.D. (1996). Rapid Least-Square Inversion of Apparent Resistivity Pseudesection. Geophysics Prospection, 44.

Telford. W. M, Geldart. L. P, \& Sheriff. R. E. (1990). Applied Geophysics, Second Edition, Cambridge and Hall, New York.

Loke, M.H. (2004). Tutorial $2 D$ and 3D Electrical Imaging Surveys, Birmingham University, England.

Hadi, S., Edi, M., Arsadi., Hartanto, P., \& Marganingrum, D. (2006). Kualitas Air Tanah Bebas Kota Karimunjawa, Pulau Karimunjawa, RISET Geologi dan Pertambangan Jilid 16. No.2, Bandung.

Sidarto, S., Santosa., \& Hermanto, B. (1993). Peta Geologi Lembar Karimunjawa, Jawa, Skala 1:100.000, Pusat Penelitian dan Pengembangan Geologi, Bandung. 